\title{
Attendance of scavenging seabirds at trawler discards off Galicia, Spain*
}

\author{
JULIO VALEIRAS \\ Instituto Español de Oceanografía, Centro Oceanográfico de Gijón, Avda Principe de Asturias, 70 bis, 33212 Gijón, \\ Asturias, Spain. E-mail: xulio.valeiras@gi.ieo.es
}

\begin{abstract}
SUMMARY: The occurrence of scavenger seabirds at fishing trawlers was studied off Galicia, Spain. A total of 9,368 seabirds of 23 species were recorded during 92 fishing operations in 1998 and 1999. The most common species were the yellow-legged and lesser black-backed gull (Larus cachinnans and L. fuscus), Sabine's gull (L. sabini), the northern gannet (Morus bassanus), the great shearwater (Puffinus gravis), sooty shearwater (P. griseus), the Manx and Balearic shearwater (P. puffinus and P. mauretanicus), the great skua (Catharacta skua) and terns (mainly Sterna hirundo and S. paradisaea). Other species occurred in small numbers: Leach's petrel (Oceanodroma leucorhoa), the storm petrel (Hydrobates pelagicus), the little shearwater (Puffinus assimilis), Cory's shearwater (Calonectris diomedea), the parasitic skua (Stercorarius parasiticus), the pomarine skua (S. pomarinus), the black-headed gull (Larus ridibundus), the glaucous gull (L. hyperboreus), the kittiwake (Rissa tridactyla), the sandwich tern (Sterna sandvicensis), the black tern (Chlidonias niger), the guillemot (Uria aalge) and the little auk (Alle alle). The maximum number of seabirds recorded at a haul was 320 . The maximum number of a particular species ranged from 120 great shearwaters to 250 yellow-legged/lesser black-backed gulls during a single haul. The differences in ship-follower species abundance are related to migratory movements but fisheries could also have a strong influence at a smaller scale on the distribution of seabirds off Galicia. The degree to which seabirds rely on fishery discards as food was not quantified, but may be important for several species.
\end{abstract}

Key words: discards, seabirds, marine fisheries, Atlantic, Galicia.

RESUMEN: ASOCIACIÓN DE LAS AVES MARINAS CON LOS DESCARTES DE LAS PESQUERÍAS DE ARRASTRE EN LA PLATAFORMA Y TALUD CONTINENTAL DE GALICIA, NW ESPAÑA. - Este trabajo estudia la asociación de aves marinas con barcos arrastreros que faenan sobre la plataforma y parte superior del talud continental de Galicia, NW España, desde junio de 1998 a marzo de 1999. Se registraron un total de 9.368 aves marinas de 23 especies durante 92 operaciones de pesca en 1998 y 1999 . Las especies más comunes fueron el grupo gaviota patiamarilla y gaviota sombría (Larus cachinnans y $L$. fuscus), la gaviota de Sabine (L. sabini), el alcatraz atlántico (Morus bassanus), la pardela capirotada (Puffinus gravis), la pardela sombría ( $P$. griseus), la pardela pichoneta y la balear ( $P$. puffinus y P.mauretanicus), el págalo grande (Catharacta skua) y los charranes (principalmente Sterna hirundo y Sterna paradisea). Otras especies se observaron en menor número: el paiño de Leach (Oceanodroma leucorhoa), el paiño europeo (Hydrobates pelagicus), la pardela chica (Puffinus assimilis), la pardela cenicienta (Calonectris diomedea), el págalo parásito (Stercorarius parasiticus), el págalo pomarino (S. pomarinus), la gaviota reidora (Larus ridibundus), el gavión hiperbóreo (L. hyperboreus), la gaviota tridáctila (Rissa tridactyla), el charrán patinegro (Sterna sandvicensis), el fumarel común (Chlidonias niger), el arao común (Uria aalge) y el mérgulo atlántico (Alle alle). El máximo número de aves marinas registrado en un arrastre fue 320. El máximo número de una especie en particular en un arrastre osciló entre las 120 pardelas capirotadas a las 250 gaviotas patiamarillas y sombrías. Los resultados indicaron diferencias en la presencia para varias especies que están relacionados con los movimientos migratorios así como con la influencia de las pesquerías en aguas de Galicia que puede ser importante a escala regional. No se cuantificó el grado en el cual las aves marinas dependen de los descartes del arrastre pero puede ser importante para varias especies.

Palabras clave: descartes, aves marinas, pesquerías, Atlántico, Galicia. 


\section{INTRODUCTION}

Many species of seabirds feed offshore and profit from fisheries discards and offal. Large feeding flocks follow fishing vessels, with spatial and temporal variations in species composition and hierarchy among the scavenging seabirds attending. Fisheries have a considerable influence at several scales on the distribution of seabirds at sea due to availability of discards as food for scavenging species (Camphuysen et al., 1995; Furness, 2000). The populations of several species have grown considerably in the last few decades, probably partly as a result of improved food resources provided by fisheries (Tasker et al., 2000). Several authors have studied distribution patterns of seabirds and their relationships with fishing discard availability and fishing boat distribution. Most studies in European waters have been in the North Sea (Furness et al., 1992; Garthe and Hüppop, 1994; Camphuysen et al., 1995). In the Mediterranean, the effects of changes in fishing activity on seabird populations have been studied and clearly shown for some species such as the rare Audouin's gull (Larus audounii) (Oro, 1996; Oro et al., 1996: Arcos, 2001).
Information on the occurrence of seabirds over the continental shelf and upper slope waters off Galicia is very scarce. A few studies describe migratory movements as seen from the shore and from some at-sea transects near the coast. Limited at-sea surveys of seabirds have provided information on pelagic species rarely seen from the coastline (Arcos et al., 1992).

The zone of study is characterised by a convergence of water masses and upwelling processes with high productivity (Tenore et al., 1982; Fraga, 1981). Demersal fish and crustacean assemblages are very abundant and rich in biodiversity. There are rich fishing grounds on the continental shelf and upper slope and a large bottom-trawling fleet operates in these waters (Fariña et al., 1997). The target species are several valuable fish including European hake (Merluccius merluccius), anglerfish (Lophius budegassa), megrims (Lepidorhombus boscii and L. wiffiagonis), horse mackerel (Trachurus sp.), blue whiting (Micromesistius poutassou) and Norway lobster (Nephrops norvegicus). The discards of this fleet in Galician waters amount to about 35-59\% of the total catch of the fleet or about 42,000 tons of discards per year (Pérez et al., 1996).

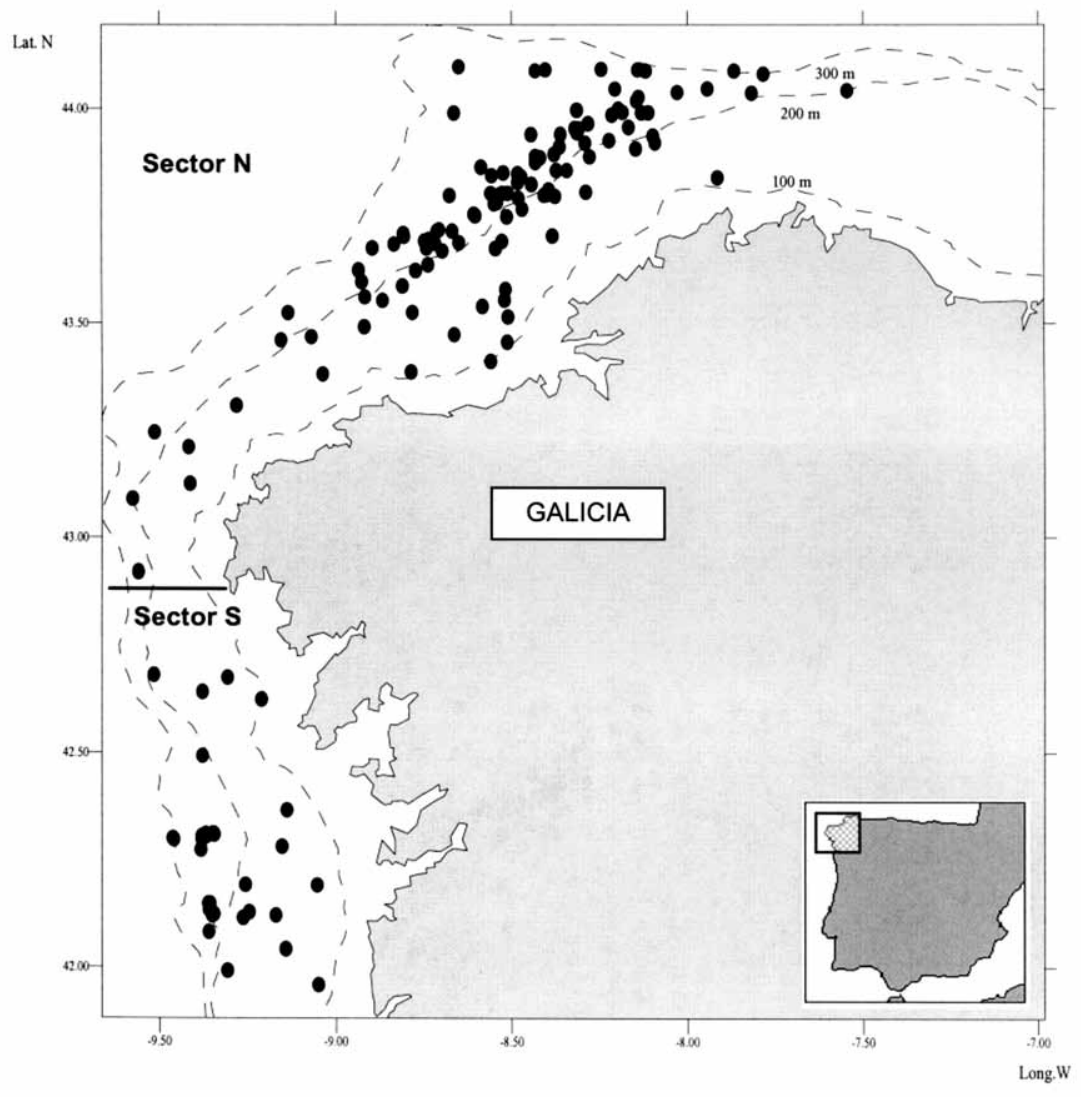

FIG. 1. - Position of bottom-trawling hauls and geographic sectors used in the study. 
The relevance and use by seabirds of this food resource has not been studied in Galician waters. The aim of this study was to gather information on the association of seabirds with trawlers and the occurrence of the different species off Galician waters based on a quantitative census of ship-followers at several fishing grounds where trawlers operate throughout the year.

\section{MATERIAL AND METHODS}

The attendance of seabirds to trawlers was monitored in 1998 and 1999 over the continental shelf and upper slope waters off Galicia. The study area was divided into two sectors that differ in their geographic and oceanographic characteristics: the $\mathrm{N}$ Sector: between $44^{\circ} 05^{\prime} \mathrm{N}$ and $43^{\circ} 00^{\prime} \mathrm{N}$ and the $\mathrm{S}$ Sector: between $43^{\circ} 00^{\prime} \mathrm{N}$ and $41^{\circ} 40^{\prime} \mathrm{N}$ (Fig. 1).

A total of 34 fishing operations were monitored monthly on board commercial trawlers in the $\mathrm{N} \mathrm{sec-}$ tor between June 1998 and March 1999. In December 1998, another 15 hauls were monitored in the $S$ sector. The data collected were complemented with censuses conducted on board R/V Cornide de Saavedra in September 1998, when it was prospecting the Galician shelf and upper slope. Seabird data were recorded during 25 and 18 hauls in the $\mathrm{N}$ and $\mathrm{S}$ sectors respectively. Fishing depth of hauls ranged from 93 to $589 \mathrm{~m}$.
Seabirds attending trawlers were counted during the fishing operations from the last moments of the hauling until the end of the process of discarding (Tasker et al., 1984; Garthe and Hüppop, 1994; Abelló et al., 2003). The highest number of individuals was recorded per species in each haul. Only the species interested in fishery discards were counted and binoculars (8x magnification) were usually used to identify species.

We gave the name 'group species' to those species (often juvenile birds) that were difficult to identify clearly in the field in order to carry out precise counts. The other seabirds were identified to the species level. These groups were formed by the yellow-legged/lesser black-backed gull (Larus cachinnans, L. fuscus), terns (Sterna hirundo, S. paradisaea and S. dougallii) and the Manx and Balearic shearwater (Puffinus puffinus, $P$. mauretanicus). The classification guarantees the accuracy of data because it avoided counting mistakes of individuals of each taxa due to the large numbers of seabirds, often juveniles, attending hauls during rough sea conditions. For this paper we have considered only data from standard hauls during daytime and we have not included censuses at night or in dusk conditions.

The results are given as mean and maximum number of birds per haul and percentage of presence (proportion of hauls in which the species was recorded) (Arcos, 2001). Seabird counts are displayed separately according to area and month.

TABLE 1. - Percentage of presence, mean and maximum number of the different species of scavenger seabirds attending bottom trawlers along the Galician coast.

\begin{tabular}{|c|c|c|c|c|}
\hline Species & Number & Presence (\% hauls) & Mean \pm SD (birds/haul) & Maximum \\
\hline Oceanodroma leucorhoa & 31 & 7 & $0.34 \pm 1.57$ & 10 \\
\hline Hydrobates pelagicus & 24 & 5 & $0.26 \pm 1.18$ & 8 \\
\hline Puffinus puffinus/mauretanicus & 192 & 28 & $2.09 \pm 5.87$ & 40 \\
\hline Puffinus gravis & 496 & 28 & $5.39 \pm 17.28$ & 120 \\
\hline Puffinus griseus & 251 & 38 & $2.73 \pm 6.81$ & 50 \\
\hline Puffinus assimilis & 1 & 1 & $0.01 \pm 0.10$ & 1 \\
\hline Calonectris diomedea & 11 & 4 & $0.12 \pm 0.71$ & 6 \\
\hline Morus bassanus & 362 & 71 & $3.93 \pm 6.58$ & 37 \\
\hline Catharacta skua & 94 & 48 & $1.02 \pm 1.91$ & 15 \\
\hline Stercorarius parasiticus & 10 & 10 & $0.11 \pm 0.35$ & 2 \\
\hline Stercorarius pomarinus & 9 & 5 & $0.10 \pm 0.56$ & 5 \\
\hline Larus cachinnans/fuscus & 7357 & 95 & $79.97 \pm 59.53$ & 250 \\
\hline Larus ridibundus & 1 & 1 & $0.01 \pm 0.10$ & 1 \\
\hline Larus sabini & 312 & 33 & $3.39 \pm 10.54$ & 85 \\
\hline Larus hyperboreus & 1 & 1 & $0.01 \pm 0.10$ & 1 \\
\hline Rissa tridactyla & 16 & 7 & $0.17 \pm 0.92$ & 8 \\
\hline Sterna hirundo/paradisaea/dougallii & 165 & 25 & $1.79 \pm 6.06$ & 45 \\
\hline Sterna sandvicensis & 15 & 8 & $0.16 \pm 0.63$ & 4 \\
\hline Chlidonias niger & 4 & 2 & $0.04 \pm 0.29$ & 2 \\
\hline Uria aalge & 1 & 1 & $0.01 \pm 0.10$ & 1 \\
\hline Alle alle & 15 & 1 & $0.16 \pm 1.56$ & 15 \\
\hline All species & 9368 & 100 & $101.83 \pm 102.31$ & 320 \\
\hline
\end{tabular}




\section{RESULTS AND DISCUSION}

\section{Species occurrence}

During the 92 fishing operations, a total of 9,368 seabirds of 23 species were observed close to vessels during hauling of the nets or discarding (Table 1). Larus gulls were observed frequently during the trips attending trawlers, often in large numbers. Yellowlegged and lesser black-backed gulls, including juveniles and adults, formed the bulk $(78.5 \%)$ of the scavenger seabirds recorded. The majority of the remainder comprised four species: the great shearwater (Puffinus gravis), the northern gannet (Morus bassanus), Sabine's gull (Larus sabini) and the sooty shearwater (Puffinus griseus). Yellow-legged and lesser black-backed gulls attended $95 \%$ of the hauls, while four other species showed high frequencies of occurrence (percentage of positive hauls): the gannet (71\%), the great skua (Stercorarius skua) (48\%), the sooty shearwater (38\%) and Sabine's gull (33\%). The smaller terns (Sterna hirundo, S. paradisaea and $S$. dougallii) and Manx-Balearic shearwaters (Puffinus puffinus, $P$. mauretanicus) were recorded at 25 and $28 \%$ of the hauls respectively. Eight other species were recorded less often: Leach's storm petrel (Oceanodroma leucorhoa), the European storm petrel (Hydrobates pelagicus), Cory's shearwater (Calonectris diomedea), the parasitic skua (Stercorarius parasiticus), the pomarine skua (Stercorarius pomarinus), the kittiwake (Rissa tridactyla), the sandwich stern (Sterna sandvicensis) and the black tern (Chlidonias niger). The remaining five species were rare and recorded occasionally attending trawlers: the blackheaded gull (Larus ridibundus), the glaucous gull (Larus hyperboreus), the little shearwater (Puffinus assimilis), the guillemot (Uria aalge) and the little auk (Alle alle). The maximum number of seabirds recorded at a single haul was 320. The maximum number of a particular species ranged from 120 great shearwaters to 250 yellow-legged/lesser blackbacked gulls during a single fishing operation. The commonest species in numbers of birds per haul (excluding yellow-legged/lesser black-backed gulls) were the great shearwater, the northern gannet, Sabine's gull, the sooty shearwater and the ManxBalearic shearwater. Mean rates for these five species ranged from 2 to 30 birds per haul, which differed in monthly and geographical occurrence (Table 2). The maximum number of species was recorded during September 1998, October 1998 and January 1999. In February 1999 only 4 seabird species were recorded. No birds were observed during two hauls in September 1998. Only yellow-legged/lesser black-backed gulls and great skuas were recorded in all months. Gannets were recorded only from June to January. The shearwater species were mostly recorded from August to October. Sabine's gulls were only observed from August to November. Small terns were only recorded from June to September.

TABLE 2. - Mean number of seabirds per haul by month and sector attending trawlers along the Galician coast.

\begin{tabular}{|c|c|c|c|c|c|c|c|c|c|c|c|c|c|c|}
\hline \multirow{3}{*}{$\begin{array}{l}\text { Geographic area } \\
\text { Month } \\
\text { Number of observed hauls }\end{array}$} & \multirow{3}{*}{$\underset{5}{\text { Jun }}$} & \multirow{3}{*}{$\begin{array}{c}\text { Jul } \\
3\end{array}$} & \multirow{3}{*}{$\underset{2}{\mathrm{Aug}}$} & \multirow{3}{*}{$\begin{array}{c}\text { Sep } \\
28\end{array}$} & \multicolumn{3}{|c|}{ N Sector } & \multirow{3}{*}{$\begin{array}{c}\text { Jan } \\
2\end{array}$} & \multirow{3}{*}{$\begin{array}{c}\mathrm{Feb} \\
2\end{array}$} & \multirow{3}{*}{$\underset{4}{\operatorname{Mar}}$} & \multirow{3}{*}{$\begin{array}{c}\text { Total } \mathrm{N} \\
59\end{array}$} & \multicolumn{3}{|c|}{ S Sector } \\
\hline & & & & & Oct & Nov & Dec & & & & & Sep & Dec & Total S \\
\hline & & & & & 6 & 5 & 2 & & & & & 18 & 15 & 33 \\
\hline Oceanodroma leucorhoa & - & 8.0 & - & 0.2 & - & - & - & - & - & - & 0.5 & 0.1 & - & 0.03 \\
\hline Hydrobates pelagicus & 3.4 & - & 2.5 & - & - & - & - & - & - & - & 0.4 & - & 0.1 & 0.1 \\
\hline $\begin{array}{l}\text { Puffinus puffinus/ } \\
\text { mauretanicus }\end{array}$ & - & 2.0 & 3.0 & 0.9 & 5.0 & - & - & 0.5 & - & - & 1.2 & 6.6 & 0.3 & 3.7 \\
\hline Puffinus gravis & - & - & 2.5 & 1.4 & 30.7 & 3.0 & - & - & - & - & 4.1 & 14.1 & - & 7.7 \\
\hline Puffinus griseus & - & - & 2.5 & 2.0 & 1.5 & - & - & - & 0.5 & - & 1.2 & 10.1 & - & 5.5 \\
\hline Puffinus assimilis & - & - & - & 0.04 & - & - & - & - & - & - & 0.0 & - & - & - \\
\hline Calonectris diomedea & 0.2 & - & 0.5 & 0.2 & 0.5 & - & - & - & - & - & 0.2 & - & - & - \\
\hline Morus bassanus & 6.6 & 1.7 & 0.5 & 6.3 & 3.5 & 1.0 & 4.0 & 17.0 & - & - & 4.8 & 2.6 & 2.2 & 2.4 \\
\hline Catharacta skua & 0.6 & 1.7 & 0.5 & 0.7 & 0.8 & 0.2 & 2.5 & 1.5 & 2.5 & 6.5 & 1.3 & 0.3 & 0.9 & 0.6 \\
\hline Stercorarius parasiticus & - & - & - & 0.3 & 0.2 & - & - & - & - & 0.3 & 0.2 & - & 0.1 & 0.03 \\
\hline Stercorarius pomarinus & - & 2.0 & - & 0.04 & 0.3 & - & - & - & - & - & 0.2 & - & - & - \\
\hline Larus cachinnans/fuscus & 50.0 & 50.0 & 37.5 & 64.7 & 37.5 & 100.0 & 100.0 & 225.0 & 40.0 & 87.5 & 69.3 & 64.8 & 140.0 & 99.0 \\
\hline Larus ridibundus & - & - & - & - & - & - & - & - & - & - & - & 0.1 & - & 0.03 \\
\hline Larus sabini & - & - & 2.0 & 5.6 & 21.3 & 1.2 & - & - & - & - & 5.0 & 0.9 & - & 0.5 \\
\hline Larus hyperboreus & - & - & - & - & - & - & - & 0.5 & - & - & 0.02 & - & - & - \\
\hline Rissa tridactyla & - & - & - & - & - & - & 4.5 & 1.5 & - & - & 0.2 & - & 0.3 & 0.1 \\
\hline \multicolumn{15}{|c|}{ Sterna hirundo/ paradisaeal } \\
\hline dougallii & 2.2 & 4.3 & 2.5 & 4.8 & - & - & - & - & - & - & 2.7 & 0.2 & - & 0.1 \\
\hline Sterna sandvicensis & - & - & - & 0.2 & - & - & - & - & - & - & 0.1 & 0.6 & - & 0.3 \\
\hline Chlidonias niger & - & - & 1.0 & 0.1 & - & - & - & - & - & - & 0.1 & - & - & - \\
\hline Uria aalge & - & - & - & - & - & - & - & 0.5 & - & - & 0.02 & - & - & - \\
\hline Alle alle & - & - & - & - & - & - & - & - & - & - & - & - & 1.0 & 0.5 \\
\hline
\end{tabular}


TABLE 3. - Recorded seabirds attending trawlers along the Galician coast per sector during September and December 1998.

\begin{tabular}{|c|c|c|c|c|c|c|c|c|c|c|c|c|}
\hline \multirow{3}{*}{$\begin{array}{l}\text { Sector } \\
\text { Month (n hauls) }\end{array}$} & \multicolumn{6}{|c|}{ Sector N } & \multicolumn{6}{|c|}{ Sector S } \\
\hline & \multicolumn{3}{|c|}{$\operatorname{Sep}(\mathrm{n}=28)$} & \multicolumn{3}{|c|}{$\operatorname{Dec}(n=2)$} & \multicolumn{3}{|c|}{$\operatorname{Sep}(n=18)$} & \multicolumn{3}{|c|}{$\operatorname{Dec}(\mathrm{n}=15)$} \\
\hline & $\% \mathrm{P}$ & Mean & Max & $\% \mathrm{P}$ & Mean & Max & $\% \mathrm{P}$ & Mean & Max & $\% \mathrm{P}$ & Mean & $\operatorname{Max}$ \\
\hline Oceanodroma leucorhoa & 7.1 & 0.2 & 3 & - & - & - & 5.6 & 0.1 & 1 & - & - & - \\
\hline Hydrobates pelagicus & - & - & - & - & - & - & - & - & - & 6.7 & 0.1 & 2 \\
\hline Puffinus puffinus/mauretanicus & 14.3 & 0.9 & 15 & - & - & - & 50.0 & 6.6 & 40 & 33.3 & 0.3 & 1 \\
\hline Puffinus gravis & 35.7 & 1.4 & 10 & - & - & - & 44.4 & 14.1 & 120 & - & - & - \\
\hline Puffinus griseus & 64.3 & 2.0 & 7 & - & - & - & 61.1 & 10.1 & 50 & - & - & - \\
\hline Puffinus assimilis & 3.6 & 0.0 & 1 & - & - & - & - & - & - & _ & - & - \\
\hline Calonectris diomedea & - & - & - & - & - & - & - & - & - & _ & - & - \\
\hline Morus bassanus & 71.4 & 6.3 & 37 & 100.0 & 4.0 & 5 & 83.3 & 2.6 & 8 & 66.7 & 2.2 & 5 \\
\hline Catharacta skua & 50.0 & 0.7 & 4 & 100.0 & 2.5 & 3 & 22.2 & 0.3 & 2 & 46.7 & 0.9 & 4 \\
\hline Stercorarius parasiticus & 21.4 & 0.3 & 2 & - & - & - & - & - & - & 6.7 & 0.1 & 1 \\
\hline Stercorarius pomarinus & 3.6 & 0.0 & 1 & - & - & - & - & - & - & - & - & - \\
\hline Larus cachinnans/fuscus & 100.0 & 64.7 & 150 & 100.0 & 100.0 & 150 & 83.3 & 64.8 & 150 & 100.0 & 140.0 & 200 \\
\hline Larus ridibundus & - & - & - & - & - & - & 5.6 & 0.1 & 1 & - & - & - \\
\hline Larus sabini & 60.7 & 5.6 & 41 & - & - & - & 22.2 & 0.9 & 6 & - & - & - \\
\hline Larus hyperboreus & - & - & - & - & - & - & - & - & - & - & - & - \\
\hline Rissa tridactyla & - & - & - & 100.0 & 4.5 & 8 & - & - & - & 20.0 & 0.3 & 2 \\
\hline Sterna hirundo/paradisaea/dougallii & 53.6 & 4.8 & 45 & - & - & - & 5.6 & 0.2 & 3 & - & - & - \\
\hline Sterna sandvicensis & 10.7 & 0.2 & 2 & - & - & - & 22.2 & 0.6 & 4 & - & - & - \\
\hline Chlidonias niger & 3.6 & 0.1 & 2 & - & - & - & - & - & - & - & - & - \\
\hline Uria aalge & - & - & - & - & - & - & - & - & - & - & - & - \\
\hline Alle alle & - & - & - & - & - & - & - & - & - & 6.7 & 1.0 & 15 \\
\hline Total & & 87.1 & 203 & & 111.0 & 159 & & 100.1 & 320 & & 144.9 & 219 \\
\hline
\end{tabular}

\section{Distribution of ship-followers}

The seabird species composition of flocks following vessels changed in each sector considered during the surveys in September and December (Table 3). In September we found 14 and 11 species at sector $\mathrm{N}$ and $\mathrm{S}$ respectively (46 hauls), which is higher than the 4 and 8 species recorded in December during 17 hauls. The occurrence of several species in September showed differences for each sector. Skuas (great skua, parasitic skua and pomarine skua) were more common in the northern sector of the study area. The highest occurrence of Sabine's gull and smaller terns was found in sector $\mathrm{N}$, which reached 60.7 and 53.6 of presence and higher mean numbers per haul. On the other hand, the shearwaters (Manx-Balearic shearwaters, great and sooty shearwater) were seen more in sector S. In general, shearwaters showed a higher presence (Manx-Balearic shearwaters were recorded in $50 \%$ of hauls) or higher numbers per haul in the southern area (Great and Sooty shearwaters). The sandwich stern was more frequent in the $\mathrm{S}$ sector. Although the number of species recorded in December was lower, the results showed similar differences between areas.

The results highlight the importance of discards as a feeding resource for many seabird species. Most seabirds are attracted by fishing vessels which pro- vide a food resource that is easily available for many species. The differences in seabird species abundance in the study area are related with migratory movements but fisheries could also have a strong influence at a smaller scale on the distribution of seabirds in Galician waters. More detailed data is required on seabird behaviour, discard availability and utilisation of discarded fish species in order to assess the potential importance of bottom trawling waste as a food source for scavenging seabirds.

\section{Discards produced by bottom trawlers}

Most of the catch discarded by the Galician trawling fishery consists of undersized commercial species and non-commercial species including fish, cephalopods and crustaceans (Pérez et al., 1996). Most commonly discarded fish are the silver pout (Gadiculus argenteus), blue whiting (Micromesistius poutassou), horse mackerel (Trachurus trachurus), boar fish (Capros aper), four-spot megrim (Lepidorhombus boscii) and snipe fish (Macroramphosus scolopax). Curled octopus (Eledone cirrhosa), squat lobsters (Munida spp.) and crabs (Polybius henslowii) are the most commonly discarded invertebrates. Length ranges by species were: 5-14 cm for silver pout, 7-25 cm for blue whiting, 9$35 \mathrm{~cm}$ for horse mackerel, $3-16 \mathrm{~cm}$ for boar fish and $10-15 \mathrm{~cm}$ for snipe fish. 
Large sized seabirds (i.e. the gannet, the yellowlegged and lesser black-backed gulls and the great skua) tended to feed on larger sized discards. Kleptoparasitic events were observed by the three species of skuas and the yellow-legged and lesser blackbacked gulls on Sabine's gull, the kittiwake and terns.

Pérez et al. (1996) estimated that 41,977 tonnes of discards came from bottom trawlers in 1994 in ICES XIIIc and IXa divisions Spanish waters (which include the study area). The influence of composition of discards and offal discharged in the Galician sea on seabirds has not yet been studied but this food resource could probably support a large part of the local and migratory seabird populations. Changes in fishing yields or the development of future regulations on Galician bottom trawl fisheries will probably influence seabird populations.

\section{ACKNOWLEDGEMENTS}

I am very grateful to the skippers and crews of the "O Cantiño", "Rías Altas", "Balayo" and "Pescarosa Segundo". Thanks also to the cruise leader of SESITS-98 survey, Francisco Sánchez from the Instituto Español de Oceanografía.

\section{REFERENCES}

Abelló, P., J.M. Arcos and L. Gil de Sola. - 2003. Geographical patterns of seabird attendance to a research trawler along the Iber- ian Mediterranean coast. Sci. Mar., 67 (Suppl. 2): 69-75.

Arcos, F., R. Salvadores and T. Salvadores. - 1992. Prospección de aves marinas desde barco en el litoral sur de Galicia (NW Iberia). Bol. GIAM, 16: 2-3.

Arcos, J.M. - 2001. Foraging ecology of seabirds at sea : Significance of commercial fisheries in the NW Mediterranean. PhD thesis. University of Barcelona. $114 \mathrm{pp}$.

Camphuysen, C.J., B. Calvo, J. Durinck, K. Ensor, A. Follestad, R.W. Furness, S. Garthe, G. Leaper, H. Skov, M.L. Tasker and C.J.N. Winter. - 1995. Consumption of discards by seabirds in the North Sea. Final report EC DG XIV research contract BIOECO/93/10. NIOZ Rapport 1995-5. Netherlands Institute for Sea Research, Texel. 202+LVI pp.

Fariña, A.C., J. Freire and E. González-Gurriarán. - 1997. Megabenthic decapod crustacean assemblages on the Galician continental shelf and upper slope (north-west Spain). Mar. Bio., 127: 419-434.

Fraga, F. - 1981. Upwelling off the Galician coast. North west, Spain. In: F. Richards (ed.), Coastal upwelling, pp. 176-182. Am. Geophys. Union. Washington.

Furness, R.W., K. Ensor and A.V. Hudson. - 1992. The use of fishery waste by gull populations around the British Isles. Ardea, 80(1): 105-113.

Furness, R.W. - 2000. Impacts of fisheries on seabird community stability. ICES CM 2000/Q:03.12 pp.

Garthe, S. and O. Hüppop. - 1994. Distribution of ship-following seabirds and their utilization of discards in the North Sea in summmer. Mar. Ecol. Prog. Ser., 106:1-9.

Oro, D. - 1996. The effects of trawler discard availability on the egg-laying and the breeding success of the lesser black-backed gull Larus fuscus in the western Mediterranean. Mar. Ecol. Prog. Ser., 132: 43-46.

Oro, D., L. Jover and X. Ruiz. - 1996. Influence of trawling activity on the breeding ecology of a threatened seabird, Audouin's gull Larus audouinii. Mar. Ecol. Prog. Ser., 139: 19-29.

Pérez, N., P. Pereda, A. Uriarte, V. Trujillo, I. Olaso and S. Lens. 1996. Descartes de la flota española en el área del ICES. Dat. Res. Inst. Esp. Oceanogr., 2: 1-142.

Tasker, M., P.H. Jones, T. Dixon and B.F. Blake. - 1984. Counting seabirds at sea from ships: a review of methods employed and a suggestion for a standardized approach. Auk, 101: 567-577.

Tasker, M.L., C.J.K. Camphuysen, J. Cooper, S. Garthe, W.A. Montevecchi and S.J.M. Blaber. - 2000. The impacts of fishing on marine birds. ICES J. mar. Sci., 57: 531-547.

Tenore, K.R., R.M. Cal, R.B. Hanson, E. López-Jamar, G.E. Santiago and J.H. Tietjen. - 1982. Coastal upwelling off the Rías Bajas, Galicia, Northwest Spain. II. Benthic studies. Rapp. P.V.Réun. Cons. Inter. Explor. Mer: 91-100. 